\title{
Can red cell distribution width be used as a predictor of acute cholecystitis?
}

\author{
Illker Murat Arer, Hakan Yabanoğlu, Kenan Çalıșkan
}

\begin{tabular}{|c|c|}
\hline \multirow[t]{5}{*}{ ABSTRACT } & $\begin{array}{l}\text { Objective: Acute cholecystitis is a common disease requiring accurate markers for diagnosis and proper treatment. } \\
\text { The aim of this study was to investigate the role of red cell distribution width (RDW) in acute cholecystitis. }\end{array}$ \\
\hline & $\begin{array}{l}\text { Material and Methods: } 299 \text { were included in the study. The subjects were divided into } 2 \text { groups; group } 1 \text { ( } \mathrm{n}: 46) \\
\text { acute cholecystitis group and group } 2 \text { (n: } 253 \text { ) chronic cholecystitis group. The patients were compared with respect } \\
\text { to demographic characteristics, white blood cell count, C-reactive protein, and red cell distribution width. }\end{array}$ \\
\hline & $\begin{array}{l}\text { Results: A statistically significant difference was observed between groups with respect to gender, white blood cell } \\
\text { count, C-reactive protein, and red cell distribution width level }(p<0.05) \text {. The mean red cell distribution width level } \\
\text { of group } 1 \text { and } 2 \text { was } 14.19 \pm 2.02 \% \text { and } 15.03 \pm 2.51 \% \text {, respectively. }\end{array}$ \\
\hline & $\begin{array}{l}\text { Conclusion: Red cell distribution width level can be used as a predictor of acute cholecystitis. Multicenter prospec- } \\
\text { tive studies should be performed to elucidate the exact role of RDW level in acute cholecystitis. }\end{array}$ \\
\hline & Keywords: Acute cholecystitis, C-Reactive protein, white blood cell count, red cell distribution width \\
\hline
\end{tabular}

Cite this paper as: Arer IM, Yabanoğlu H, Çalışkan K. Can red cell distribution width be used as a predictor of acute cholecystitis?. Turk J Surg 2017; 33(2): 76-79

Department of General Surgery, Başkent University Adana Application and Research Center, Adana, Turkey

Address for Correspondence illker Murat Arer e-mail: igy1981@yahoo.com

Received: 23.09 .2015 Accepted: 01.12.2015

C) Copyright 2017 by Turkish Surgical Association www.turkjs

\section{INTRODUCTION}

Acute cholecystitis (AC) is among the most common reasons of acute abdomen presenting to emergency departments and is commonly related to the obstruction of the cystic duct mainly with gallstones. The prevalence of cholelithiasis is reported as $10-15 \%$, and approximately $35 \%$ of these patients develop complications or recurrent symptoms in their lifetime (1, 2). Although more than $70 \%$ of patients with acute cholecystitis respond to medical treatment within the first 24-48 hours, laparoscopic cholecystectomy (LC) is the definitive treatment of symptomatic cholelithiasis and its complications. Early LC has been reported to have lower complication rates than open cholecystectomy (OC) (3). Although the timing of LC remains controversial, early LC is recommended for reduction of complication rate and length of hospital stay (4-7). Early diagnosis of acute cholecystitis is necessary for the decision of surgery.

The diagnosis of $\mathrm{AC}$ is based on severe abdominal pain at the right upper abdominal quadrant and localized tenderness (with or without a positive Murphy's sign) together with vomiting, fever and leukocytosis (8). Ultrasound findings support acute cholecystitis $(9,10)$. Diagnosis of AC can also be confirmed by pathology findings.

The laboratory tests can be easily performed and facilitate AC diagnosis, which include; complete blood count (CBC), C-Reactive protein (CRP) and liver function tests. CBC includes leukocyte, erythrocyte and thrombocyte counts and also morphological features such as red cell distribution width (RDW). Red cell distribution width level has been reported to be a predictor of diseases such as coronary artery disease, inflammatory bowel disease, celiac disease and pulmonary embolism, and has been reported to be valuable in diagnosis of diseases such as acute pancreatitis, bacteremia, sepsis, and septic shock $(11,15-17)$. However, the role of RDW in diagnosis of AC remains unclear. The aim of this study was to investigate the role of RDW in AC.

\section{MATERIAL AND METHODS}

All patients who underwent laparoscopic cholecystectomy between January 2013 and July 2014 in Başkent University Adana Application and Research Center General Surgery Department were included in the study. Patients were divided into two groups according to their final pathology reports. Group-1 consisted of patients with acute cholecystitis while group-2 consisted of patients with chronic cholecystitis (CC). Data was collected retrospectively. Demographic data such as age and sex, physical findings (Murphy's sign), white blood cell count, RDW level, CRP level, ultrasound findings, pathology report, ASA (American Society of Anesthesiologists) score and complications were recorded. Exclusion criteria 
included cholangitis, choledocholithiasis, acute pancreatitis, malignancy, and a history of percutaneous or endoscopic biliary drainage prior to surgery.

This study was approved by Başkent University Institutional Review Board (Project No: KA14/258) and supported by Başkent University Research Fund. Informed consent was not taken because of the retrospective design of this study.

\section{Laboratory Tests}

Leukocyte counts were obtained by an electronic cell counter (Advia 2120i; Hematology System with Autoslide, Siemens, Erlangen, Germany). Serum CRP levels were measured by spectrophotometric methods (Cobas Integra 800; Roche, Mannheim, Germany). The normal range of RDW level in our laboratory was $11.3-15.2 \%$, that of leukocyte count was 4 and $11.5 \times 10^{3} / \mu \mathrm{L}$, and that of CRP level was $0-6 \mathrm{mg} / \mathrm{L}$.

\section{Statistical Analysis}

Statistical Package for the Social Sciences software package was used for statistical analysis (version 17.0, SPSS Inc.; Chicago, IL, USA). If continuous variables were normal, they were presented as mean \pm standard deviation $(p>0.05$ in Kolmogorov-Smirnov test or Shapira-Wilk $(n<30)$ ), and if the continuous variables were not normal, they were presented as median values. Comparisons between groups were applied using one-way Student T test and One Way ANOVA for normally distributed data. Values of $p<0.05$ were considered statistically significant.

\section{RESULTS}

Group- 1 consisted of 46 patients while there were 253 patients in group-2, yielding a total of 299 subjects (206 female, 93 male). Within the group of 299 patients, 144 had positive physical findings and Murphy's sign (48.2\%). There was no significant difference between groups according to age and ASA-score $(p>0.05)$. A significant difference was determined between group-1 and 2 in terms of gender $(p=0.001)$ (Table 1$)$. Ultrasound findings revealed acute cholecystitis in 37 (12.4\%), and chronic cholecystitis in 152 (50.8\%) patients. In 110 (36.8\%) patients, ultrasound was performed in another clinic. Detailed radiologic evaluation (e.g. Computed Tomography or Magnetic Resonance Cholongiopancreatography) was performed in 39 patients. Ten (3.3\%) of these 39 patients were accepted as acute cholecystitis based on the findings of detailed radiologic evaluation (Table 2). The ASA-score of patients are listed in Table 3. The mean WBC count was $13.3 \pm 5.5 \times 10^{3} / \mu \mathrm{L}$ and $8.8 \pm 2.8$ $\mathrm{x} 10^{3} / \mu \mathrm{L}$ for group 1 and 2 , respectively. The WBC count was significantly high in the AC group $(p=0.001)$. Mean CRP level was $79.94 \pm 93.06 \mathrm{mg} / \mathrm{L}$ in the AC group and $32.94 \pm 51.27 \mathrm{mg} / \mathrm{L}$ in the CC group. The CRP level in the AC group was significantly high as compared with the CC group $(p=0.030)$. However, the CRP level was recorded in only 17 of $46 \mathrm{AC}$ and 30 of $253 \mathrm{CC}$ patients, which is the main limitation of our study regarding CRP level comparison. The mean RDW level was $14.19 \pm 2.02 \%$ in the AC group and $15.03 \pm 2.51 \%$ in the CC group. The RDW level was significantly low in the AC group ( $p=0.034)$. Receiver operating characteristic (ROC) curve analysis showed the best cut-off value for RDW level in the diagnosis of AC as $14.15 \%$ with a sensitivity of $64.8 \%$ and a specificity of $56.5 \%$ (area under curve [AUC]: 0.611, $\mathrm{p}=0.017$; Figure 1). Receiver operating characteristic curve analysis identified the best cut-off value
Table 1. Comparison of the demographic features and White blood cell count, CRP, and RDW levels of the subjects in acute and chronic cholecystitis groups

\begin{tabular}{|lccc|} 
& $\begin{array}{c}\text { Acute } \\
\text { cholecystitis } \\
(\mathbf{n}=46)\end{array}$ & $\begin{array}{c}\text { Chronic } \\
\text { cholecystitis } \\
(\mathbf{n}=253)\end{array}$ & $\mathbf{p}$ \\
\hline Male/Female & $24 / 22$ & $69 / 184$ & 0.001 \\
\hline Age $(\text { years })^{*}$ & $49.15 \pm 14.2$ & $50.95 \pm 14.56$ & 0.441 \\
\hline $\mathrm{WBC}\left(\mathrm{x} 10^{3} / \mu \mathrm{L}\right)^{*}$ & $13.3 \pm 5.5$ & $8.8 \pm 2.8$ & 0.001 \\
\hline $\mathrm{CRP}(\mathrm{mg} / \mathrm{L})^{*}$ & $79.94 \pm 93.06$ & $32.94 \pm 51.27$ & 0.030 \\
\hline $\mathrm{RDW}(\%)^{*}$ & $14.19 \pm 2.02$ & $15.03 \pm 2.5$ & 0.034 \\
\hline
\end{tabular}

*Values are mean \pm standard deviation.

CRP: C-reactive protein; RDW: red cell distribution width; WBC: white blood cell count

Table 2. Detailed radiologic evaluation

\begin{tabular}{|lcc|}
\hline & Frequency (n) & Percent (\%) \\
\hline Acute cholecystitis (CT) & 8 & 2 \\
\hline Acute cholecystitis (MRCP) & 1 & 0.3 \\
\hline Gangrenous cholecystitis (CT) & 1 & 0.3 \\
\hline Normal (CT) & 4 & 1.3 \\
\hline Cholelithiasis (MRCP) & 25 & 8.4 \\
\hline None & 260 & 87 \\
\hline Total & 299 & 100 \\
\hline
\end{tabular}

CT: computed tomography, MRCP: magnetic resonance cholangiopancreatography

\begin{tabular}{|lcc|}
\hline Table 3. ASA score of patients & & \\
\hline ASA score & Frequency & Percent \\
\hline 1 & 44 & 14.7 \\
\hline 2 & 175 & 58.5 \\
\hline 3 & 79 & 26.4 \\
\hline 4 & 1 & 0.3 \\
\hline Total & 299 & 100 \\
\hline
\end{tabular}

ASA: American Society of Anesthesiologists

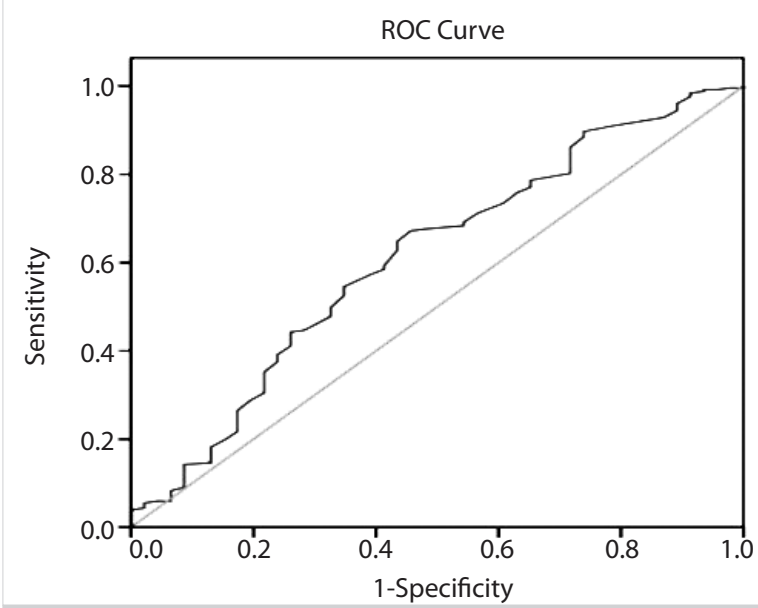

Figure 1. Receiver operating characteristic (ROC) curve of red cell distribution width (RDW) 


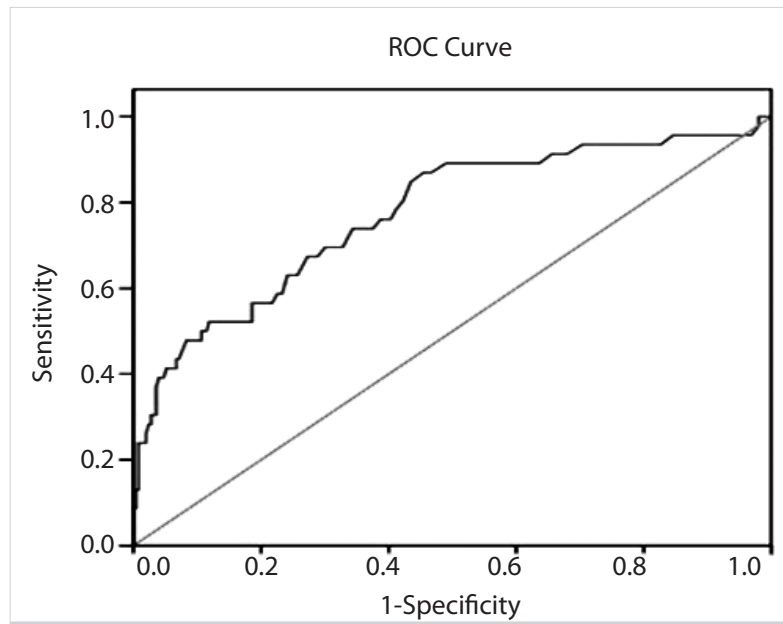

Figure 2. Receiver operating characteristic (ROC) curve of white blood cell (WBC) count

for WBC count in the diagnosis of AC as $9.9 \times 10^{3} / \mu \mathrm{L}$ with a sensitivity of $69.6 \%$ and a specificity of $70 \%$ (area under curve [AUC]: 0.773, $p=0.0001$; Figure 2). No complication was observed in both groups.

\section{DISCUSSION}

Acute cholecystitis (AC) is among the most common reasons of acute abdomen presenting to emergency departments. Early diagnosis is essential for the decision of cholecystectomy timing. Early cholecystectomy, especially within 72 hours of admission, is recommended in order to decrease the complication rate and length of hospital stay (4-7). In a large randomized trial, Gutt et al. (18) showed that laparoscopic cholecystectomy was superior to conservative approach in terms of morbidity and cost. Therefore, early diagnosis and surgical decision making are crucial steps in the management of $A C$.

Elevated white blood cell count and CRP levels are common laboratory tests used in the diagnosis of AC. In our study, WBC count was found to be significantly high in the AC group, in parallel with previous reports $(7,19)$. The mean WBC count in our study was $13.3 \pm 5.5 \times 10^{3} / \mu \mathrm{L}$. Wevers et al. (19) determined the mean WBC count as $12.6-13.1 \times 10^{3} / \mu \mathrm{L}$. This elevated value may be due to high patient population presenting with severe cholecystitis. Although they did not report the exact WBC count in their series, Oymaci et al. (7) defined leukocytosis as WBC count higher than $10 \times 10^{3} / \mu \mathrm{L}$ and $70-73 \%$ of their patients had leukocytosis. Nikfarjam et al. (20) found median WBC count as $11.7 \times 10^{3} / \mu \mathrm{L}$. In our study, the median WBC count was $12.5 \times 10^{3} / \mu \mathrm{L}$ that is higher than that reported in the literature.

C-reactive protein level was also found to be elevated in AC, especially to very high values when gangrenous cholecystitis is present and Crp level is alsocorrelated with conversion to open cholecystectomy (19-21). In our study, the mean CRP level was $79.94 \pm 93.06 \mathrm{mg} / \mathrm{L}$ in the AC group and was statistically significant as compared to the CC group $(p=0.030)$.

We aimed to seek another laboratory test that may aid in differentiating AC from CC. Red cell distribution width is anemia, thalassemia and hemoglobinopathies, while it can also reflect an inflammation $(12,22)$. Increased RDW levels are detected in cases of red blood cell production or degradation impairment (12). Higher RDW levels were found to be associated with worse clinical outcomes in patients with heart failure, coronary artery disease, pulmonary hypertension, diabetes mellitus, and stroke (13-15, 22-24). Pro-inflammatory cytokines of sepsis influence the half-life of circulating erythrocytes, damage their membranes and suppress maturation, lead to introduction of larger and newer reticulocytes to systemic circulation thus increasing the RDW. In addition, high oxidative stress can also reduce erythrocyte lifetime and increase the release of premature red blood cells into the blood stream. Sadaka et al. (25) demonstrated RDW to be associated with mortality and morbidity on the first day of septic shock. Meynaar et al. (26) showed that RDW level on Intensive Care Unit (ICU) admission was an independent predictor of mortality, but the mechanism of this association needs to be further investigated. Senol et al. (17) demonstrated that increased RDW-level on admission is an independent risk factor of mortality in patients with acute pancreatitis. Jo et al. (16) observed that RDW is associated with early mortality in severe sepsis and septic shock. the median RDW-level was similar in the non-survivor groups of both studies $(16,17)$. Increased RDW-level has been shown to be associated with elevated CRP, erythrocyte sedimentation rate, and interleukin-6 levels $(22,25,27)$. Narci et al. (28) determined decreased RDW level in patients with acute appendicitis with a sensitivity and specificity of $47 \%$ and $67 \%$, respectively. However, the difference was so slight that it was concluded that RDW could not be used in diagnostic testing. Yao et al. (29) also found a significant association between RDW and mortality in acute pancreatitis, and the sensitivity and specificity of RDW level to predict mortality were identified as $75 \%$ and $89.8 \%$, respectively. In the literature, there are several studies evaluating the association between RDW level and acute pancreatitis or acute appendicitis, but no study was found to evaluate acute cholecystitis. Our study was designed to assess the correlation of acute cholecystitis and RDW level. We observed significant difference between RDW level and acute cholecystitis and mean RDW level was lower in AC group but still in normal range. We determined the sensitivity and specificity of RDW level in the diagnosis of AC as $64.8 \%$ and $56.5 \%$, respectively.

We want to emphasize that mean RDW level in the CC group was $15.03 \%$, which is close to the upper range of normal RDW level. The retrospective design of our study is one of its limitations. In addition, our control group consisted of patients with chronic cholecystitis, comparison versus the normal population without any inflammatory process may have yielded better results.

\section{CONCLUSION}

Elevated white blood cell count and C-reactive protein levels are predictors of acute cholecystitis. Red cell distribution width level has a similar significant role, which can be used as a predictor of acute cholecystitis. Multicenter prospective are required on this issue to further elucidate the role of RDW level in acute cholecystitis. 
Ethics Committee Approval: Ethics committee approval was received for this study from the ethics committee of Başkent University Institutional Review Board (Project No: KA14/258).

Informed Consent: Informed consent was not received due to the retrospective nature of the study.

Peer-review: Externally peer-reviewed.

Author Contributions: Concept - I.M.A., H.Y.; Design - I.M.A., H.Y.; Supervision - H.Y., K.Ç.; Resource - I.M.A.; Materials - I.M.A., H.Y.; Data Collection and/or Processing - I.M.A. ,H.Y., K.Ç.; Analysis and/or Interpretation - I.M.A.; Literature Search - K.Ç.; Writing Manuscript - I.M.A.; Critical Reviews - H.Y., K.Ç.

Conflict of Interest: No conflict of interest was declared by the authors.

Financial Disclosure: The authors declared that this study has received no financial support.

\section{REFERENCES}

1. Shaffer EA. Gallstone disease: epidemiology of gallbladder stone disease. Best Pract Res Clin Gastroenterol 2006; 20: 981-996. [CrossRef]

2. Schirmer BD, Winters KL, Edlich RF. Cholelithiasis and cholecystitis. J Long Term Eff Med Implants 2005; 15: 329-338. [CrossRef]

3. Kiviluoto T, Sir'en J, Luukkonen P, Kivilaakso E. Randomised trial of laparoscopic versus open cholecystectomy for acute and gangrenous cholecystitis. Lancet 1998; 351: 321-325. [CrossRef]

4. Kolla S. B, Aggarwal S, Kumar A, Kumar R, Chumber S, Parshad R. Early vs delayed laparoscopic cholecystectomy for acute cholecystitis: a prospective randomized trial. Surg Endosc 2004; 18: 1323-1327. [CrossRef]

5. Siddiqui T, MacDonald A, Chong P. S, Jenkins J. T. Early versus delayed laparoscopic cholecystectomy for acute cholecystitis: a meta-analysis of randomized clinical trials. Am J Surg 2008; 195:40-47. [CrossRef]

6. Gurusamy K. S, Davidson C, Gluud C, Davidson B. R. Early versus delayed laparoscopic cholecystectomy for people with acute cholecystitis. Cochrane Database Syst Rev 2013; 6: CD005440. [CrossRef]

7. Oymaci E, Ucar AD, Yakan S, Carti EB, Coskun A, Erkan N, et al. Determination of optimal operation time for the management of acute cholecystitis: a clinical trial. Prz Gastroenterol 2014; 9: 147152. [CrossRef]

8. Al-Azawi D, Mc Mahon D, Rajpal PK. The diagnosis of acute cholecystitis in patients undergoing early laparoscopic cholecystectomy in a community hospital Surg Laparosc Endosc Percutan Tech 2007; 17: 19-21. [CrossRef]

9. Cho KS, Baek SY, Kang BC, Choi HY, Han HS. Evaluation of preoperative sonography in acute cholecystitis to predict technical difficultiesduring laparoscopic cholecystectomy. J Clin Ultrasound 2004; 32: 115-122.[CrossRef]

10. Bingener J, Schwesinger WH, Chopra S, Richards ML, Sirinek KR. Does the correlation of acute cholecystitis on ultrasound and at surgery reflect a mirror image? Am J Surg 2004; 188: 703-707. [CrossRef]

11. Harmanci O, Kav T, Sivri B. Red cell distribution width can predict intestinal atrophy in selected patients with celiac disease. J Clin Lab Anal 2012; 26: 497-502. [CrossRef]

12. Öztürk ZA, Ünal A, Yiğiter R, Yesil Y, Kuyumcu ME, Neyal Met, et al. Is increased red cell distribution width (RDW) indicating the inflammation in Alzheimerss disease (AD)? Arch Gerontol Geriatr 2013; 56: 50-54. [CrossRef]

13. Felker GM, Allen LA, Pocock SJ, Shaw LK, McMurray JJ, Pfeffer MA et al. Red cell distribution width as a novel prognostic marker in heart failure: data from the CHARM Program and the Duke Databank. J Am Coll Cardiol 2007; 50: 40-47. [CrossRef]

14. Hampole CV, Mehrotra AK, Thenappan T, Gomberg-Maitland M, Shah SJ. Usefulness of red cell distribution width as a prognostic marker in pulmonary hypertension. Am J Cardiol 2009; 104: 868872. [CrossRef]

15. Tonelli M, Sacks F, Arnold M, Moye L, Davis B, Pfeffer M. For the Cholesterol and Recurrent Events (CARE) Trial Investigators: Relation between red blood cell distribution width and cardiovascular event rate in people with coronary disease. Circulation 2008; 117: 163-168. [CrossRef]

16. Jo YH, Kim K, Lee JH, Kang C, Kim T, Park HM, et al. Red cell distribution width is a prognostic factor in severe sepsis and septic shock. Am J Emerg Med 2013; 31: 545-548. [CrossRef]

17. Senol K, Saylam B, Kocaay F, Tez M. Red cell distribution width as a predictor of mortality in acute pancreatitis. Am J Emerg Med 2013; 31: 687-689. [CrossRef]

18. Gutt CN, Encke J, Köninger J, Harnoss JC, Weigand K. Acute cholecystitis: early versus delayed cholecystectomy, a multicenter randomized trial. Ann Surg 2013; 258: 385-393. [CrossRef]

19. Wevers KP, van Westreenen HL, Patijn GA. Laparoscopic cholecystectomy in acute cholecystitis: C-reactive protein level combined with age predicts conversion Surg Laparosc Endosc Percutan Tech 2013; 23: 163-166. [CrossRef]

20. Nikfarjam M, Niumsawatt $V$, Sethu A, Fink MA, Muralidharan $V$ Starkey $G$, et al. Outcomes of contemporary management of gangrenous and non-gangrenous acute cholecystitis. HPB (Oxford) 2011; 13: 551-558. [CrossRef]

21. Mok KW, Reddy R, Wood F, Turner P, Ward JB. Is C-reactive protein a useful adjunct in selecting patients for emergency cholecystectomy by predicting severe/gangrenous cholecystitis? Int J Surg 2014; 12: 649-653. [CrossRef]

22. Lippi G, Targher G, Montagnana M, Salvagno GL, Zoppini G, Guidi GC. Relation between red blood cell distribution width and inflammatory biomarkers in a large cohort of unselected outpatients. Arch Pathol Lab Med 2009; 133: 628-632.

23. Ani C, Ovbiagele B. Elevated red blood cell distribution width predicts mortality in persons with known stroke. J Neurol Sci 2009; 277: 103-108. [CrossRef]

24. Malandrino N, Wu WC, Taveira TH, Whitlatch HB, Smith RJ. Association between red blood cell distribution width and macrovascular and microvascular complications in diabetes. Diabetologia 2012; 55: 226-235. [CrossRef]

25. Sadaka F, O'Brien J, Prakash S. Red cell distribution width and outcome in patients with septic shock. J Intensive Care Med 2013; 28: 307-313. [CrossRef]

26. Meynaar IA, Knook AH, Coolen S, Le H, Bos MM. Red cell distribution width as predictor for mortality in critically ill patients. Neth J Med 2013; 71: 488-493.

27. Perlstein TS, Weuve J, Pfeffer MA, Beckman JA. Red blood cell distribution width and mortality risk in a community-based prospective cohort. Arch Intern Med 2009; 169: 588-594. [CrossRef]

28. Narci $H$, Turk E, Karagulle E, Togan $T$, Karabulut $K$. The role of red cell distribution width in the diagnosis of acute appendicitis: a retrospective case-controlled study World J Emerg Surg 2011; 8: 46. [CrossRef]

29. Yao J, Lv G. Association between red cell distribution width and acute pancreatitis: a cross-sectional study. BMJ Open 2014; 4: e004721. [CrossRef] 